\title{
Aedes vittatus in Spain: current distribution, barcoding characterization and potential role as a vector of human diseases
}

\author{
Alazne Díez-Fernández ${ }^{1 *}$ (D) Josué Martínez-de la Puente ${ }^{1,2}$, Santiago Ruiz²,3, Rafael Gutiérrez-López ${ }^{1}$ \\ Ramón Soriguer ${ }^{1,2}$ and Jordi Figuerola ${ }^{1,2}$
}

\begin{abstract}
Background: Aedes vittatus is currently found in Africa, Asia and Europe, where it acts as a vector of pathogens causing animal and human diseases (e.g. chikungunya, Zika and dengue). Like other Aedes species, Ae. vittatus is able to breed in artificial containers. The ECDC has recently highlighted the need for molecular tools (i.e. barcoding characterization) that enable Aedes species to be identified in entomological surveys.

Results: We sampled mosquito larvae and adults in southern Spain and used a molecular approach to amplify and sequence a fragment of the cytochrome $c$ oxidase subunit 1 gene (barcoding region) of the mosquitoes. The blast comparison of the mosquito sequences isolated from Spain with those deposited in public databases provided a $\geq 99 \%$ similarity with sequences for two Aedes mosquitoes, Ae. vittatus and Ae. cogilli, while similarities with other Aedes species were $\leq 94 \%$. Aedes cogilli is only present in India and there are no records of this species from Europe.

Conclusions: Due to the low genetic differences between Ae. vittatus and Ae. cogilli, the barcoding region should not be used as the only method for identifying Ae. vittatus, especially in areas where both of these Aedes species are present. This type of analysis should thus be combined with morphological identification using available keys and/or the characterization of other molecular markers. In addition, further entomological surveys should be conducted in order to identify the fine-scale distribution of this mosquito species in Europe.
\end{abstract}

Keywords: DNA barcoding, Aedes mosquitoes, Vector-borne diseases

\section{Background}

Vector-borne pathogens are a global health concern in which mosquitoes play a central role as vectors of pathogens [1]. In Europe both native and invasive species of Aedes mosquitoes are involved in the transmission of pathogens including viruses (e.g. dengue and chikungunya [2]) and parasites (e.g. Dirofilaria [3]). Of these mosquitoes, the invasive Aedes albopictus has received much attention in recent decades due to its role in the transmission of dengue [4] and chikungunya [5] in Europe. Certain Aedes species, including Ae. albopictus, are able to breed in artificial containers and it is

\footnotetext{
* Correspondence: adiezfer@ebd.csic.es

${ }^{1}$ Estación Biológica de Doñana (EBD-CSIC), Calle Américo Vespucio 26,

E-41092 Seville, Spain

Full list of author information is available at the end of the article
}

important to develop accurate identification protocols for differentiating native and invasive Aedes species that breed in the same area [6-8]. The identification of mosquito species through the characterization of a fragment of the cytochrome $c$ oxidase subunit 1 ( $\operatorname{cox} 1)$ gene is a useful tool for monitoring the presence of species $[9,10]$, above all given the difficulties in identifying mosquitoes in larval stages and the current scarcity of trained taxonomists [11]. However, this method requires a previous genetic characterization of the species [12]. This is an important limitation in the case of Aedes mosquitoes as this information is not available for most of the species of this genus that breed in Europe [13], despite their importance in pathogen transmission [14].

The aim of this study was to update the current distribution of Ae. vittatus and provide the first 
genetic characterization of the barcoding region of specimens of this species from Europe. Hitherto, sequences from this species were only available from China [15], India [16] and Kenya [17]. In addition, we review here available information on the potential role of this species in the transmission of virus of public health concern.

\section{Methods}

As a part of an extensive mosquito-monitoring program, a female Ae. vittatus was captured in a CDC trap in Aya-

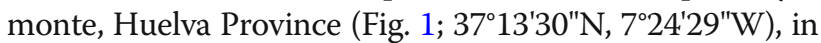
June 2015. This sampling site is located in the Guadiana marshes, in the garden of a house close to the built-up area of Ayamonte. At the same time, we also trapped 19 Ochlerotatus caspius. In further trapping sessions during 2015 in this area we captured 1145 Oc. caspius, 47 Oc. detritus, 9 Cx. pipiens, 4 Cx. theileri, 3 Cx. perexiguus, 3 Culiseta longiareolata and 2 Cs. annulata. Additionally, mosquito larvae were collected from a container in July 2015 in a rural property near Castilblanco de los Arroyos, Seville Province (Fig. 1; 374 $41^{\prime} 56^{\prime \prime} \mathrm{N}, 5^{\circ} 58^{\prime} 44^{\prime \prime} \mathrm{W}$ ), in an area characterized by the presence of isolated houses surrounded by scrubland. Larvae were maintained in plastic trays with natural water and fed ad libitum with Mikrozell (Hobby Mikrozell $20 \mathrm{ml} / 22 \mathrm{~g}$ ) in a climatic chamber at constant conditions $\left(28{ }^{\circ} \mathrm{C}, 65-70 \%\right.$ relative humidity $(\mathrm{RH})$ and 12:12 light:dark photocycle). Adult mosquitoes were fed ad libitum with $1 \%$ sugar solution. Five to seven days after emergence, adult mosquitoes were anaesthetised with diethyl ether and identified to species level using available taxonomic keys [18, 19] under a stereo-microscope (Nikon SMZ645). The ability of laboratory-reared females to bite humans was checked by exposing the arm of one of the authors (RGL) to mosquito bites. The time elapsed between arm exposure and the beginning of blood-feeding was recorded.

Three mosquitoes (one male and two females) from Seville Province were selected for molecular characterization of the barcoding region and to confirm the morphological identification of the species. A fragment of the right hind-leg of each mosquito was cut-off using a sterile blade and placed on a Petri dish. Genomic DNA was extracted using the Maxwell 16 LEV Blood DNA Kit (Promega, Madison, WI, USA) following the manufacture's instructions. PCR reactions were performed using the primer pair LCO1490 (5'-GGT CAA CAA ATC ATA AAG ATA TTG G-3') and HCO2198 (5'-TAA ACTT CAG GGT GAC CAA AAA ATC A-3') [20] following Whiteman et al. [21] to amplify a $658 \mathrm{bp}$ fragment of the cox 1 gene (excluding primers) (see [22]). The presence of amplicons was verified on $1.8 \%$ agarose gels. Sequences were resolved in both directions by Macrogen sequencing service (Macrogen Inc., the Netherlands). Sequences were edited using the SequencherTM v4.9 software (Gene Codes Corp., Ann Arbor, MI, USA) and compared with sequences deposited in the GenBank DNA sequence database (National Center for Biotechnology Information) and the Barcode of Life Data Systems (BOLD).

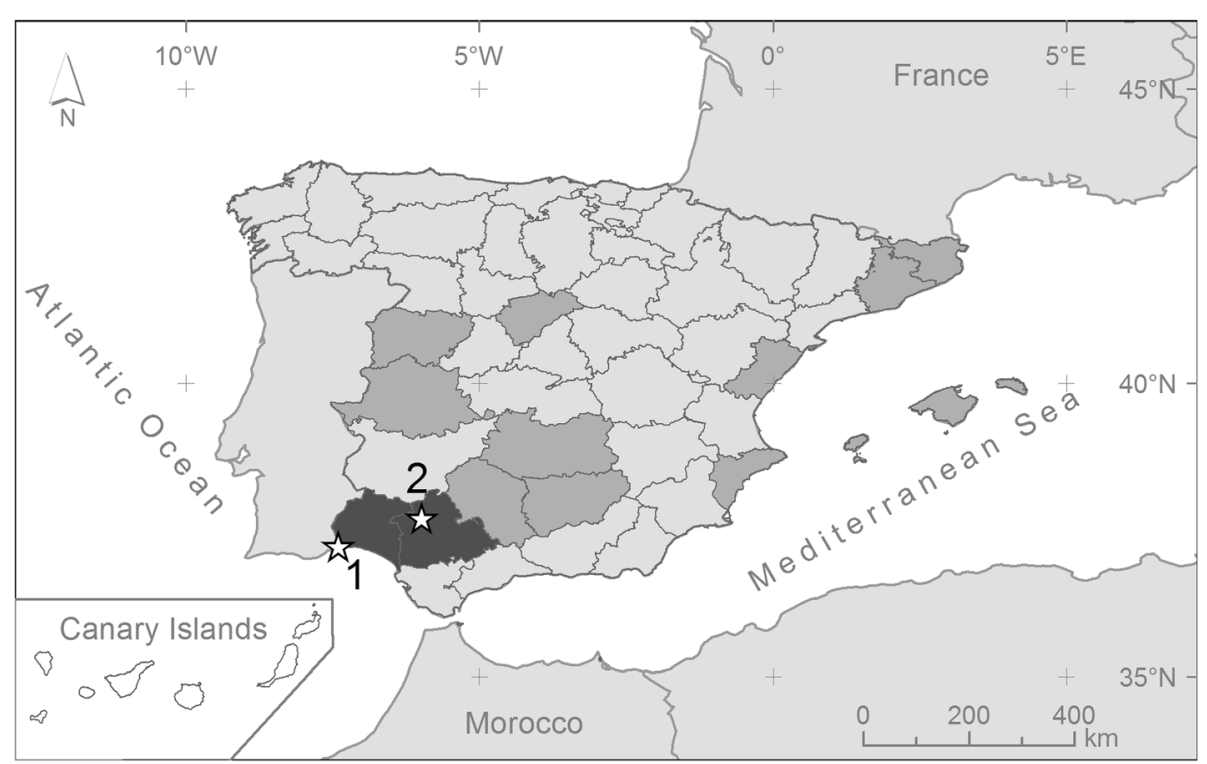

Fig. 1 Distribution by provinces of Ae. vittatus in Spain. Light grey and dark grey indicates the provinces where the species is absent or present, respectively. The two new records of Ae. vitattus reported in this study are marked with stars: 1. Ayamonte (Huelva Province), 2. Castilblanco de los Arroyos (Seville Province) 


\section{Results}

Mosquitoes were morphologically identified as Ae. vittatus (Fig. 2). Genetic characterization of the barcoding region of the three mosquitoes provided a unique haplotype. Using the BOLD system, the sequences obtained in our study were identified as Ae. vittatus (99.4\%) or Aedes (Phagomyia) cogilli (99.0\%). Likewise, a 99\% overlap between Ae. vittatus and Ae. cogilli was found using a BLAST comparison with sequences in GenBank, while similarities with other Aedes species were $\leq 94 \%$.

The anthropophilic feeding preference of Ae. vittatus females was confirmed by the fact that four mosquitoes $(57.1 \%)$ fed on a human arm after $<5 \mathrm{~min}$ of exposure.

\section{Discussion}

We characterized for the first time in Europe the barcoding region of Ae. vittatus. A BLAST comparison of this sequence with those deposited in public

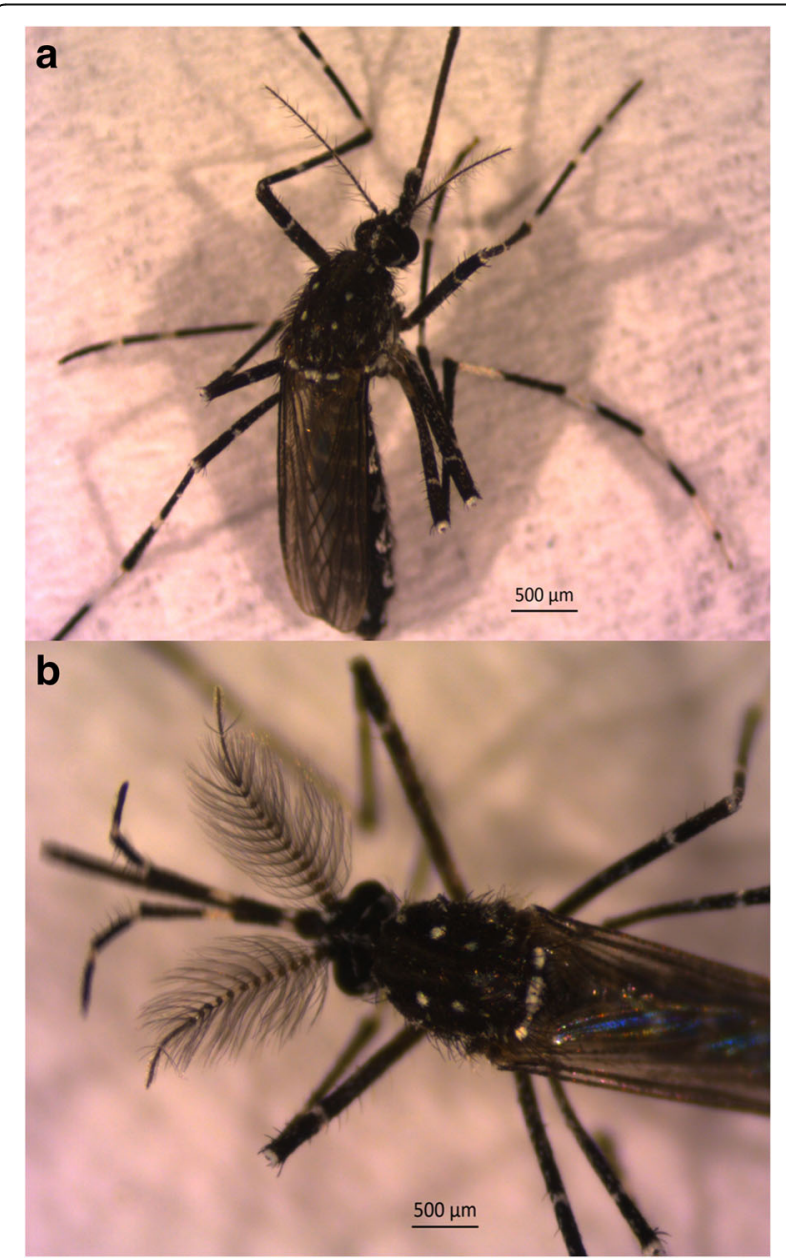

Fig. 2 Aedes vitattus female (a) and male (b) captured in the Seville Province databases provided a $\geq 99 \%$ similarity with sequences of two Aedes mosquitoes, Ae. vittatus and Ae. cogilli. However, Ae. cogilli, is only present in India and is not found in Europe [23]. The other Aedes sequences on GenBank differed by about 6\% from the Ae. vittatus sequence isolated here. Although varying between taxa, interspecific differences in the barcoding region are established at $0-2 \%$ [24]. Based on the low interspecific differences found between Ae. vittatus and Ae. cogilli, our results do not support the use of the cox 1 region as a method for separating these species where they coincide; rather, this method should be combined with morphological identification using available keys or the characterization of other molecular markers. Based on the morphological characteristics of the specimens captured here, we conclude that the mosquitoes we captured belong to the species Ae. vittatus [25].

The current distribution of Ae. vittatus includes rural and natural areas in Africa, Asia and European countries in the Mediterranean Basin such as France, Italy, Portugal and Spain (Fig. 3). Specifically, Ae. vitattus has been recorded with a clear discontinuous distribution from eleven Spanish provinces [26]. Larvae of Ae. vittatus have been recorded in a variety of habitats including rock pools, tree holes, domestic containers and hoofprints [27, 28]. In eastern Spain, this species is present in coastal mountainous areas of thermomediterranean and lower mesomediterranean thermotypes [29]. Here, we update the distribution of this species in the Iberian Peninsula and provide the first reports of its presence in the provinces of Huelva and Seville (Fig. 1). In Huelva, an adult female was trapped close to a built-up area, while mosquito larvae belonging to this species were sampled in a rural property in Seville. The mosquito from Huelva was captured in an area close to the town of Ayamonte, which suggests the possibility of contact between this mosquito species and human populations.

The fact that Ae. vittatus uses artificial containers for breeding in rural ecosystems may be particularly relevant given its ability to transmit pathogens causing human diseases. In addition to humans, Ae. vittatus feed on bovids, sheep/goats and porcupines [30, 31], suggesting its potential role in the transmission cycle of a variety of arboviruses (Table 1). Although Ae. vittatus has also been reported to be involved in the transmission of viruses potentially affecting humans, including species of Alphavirus, Flavivirus and Bunyavirus (Table 1), this species probably only has a low risk in Spain. Diagnosis of these diseases and vector surveillance will help elucidate the potential role of Ae. vittatus in the transmission of viruses in Europe. 


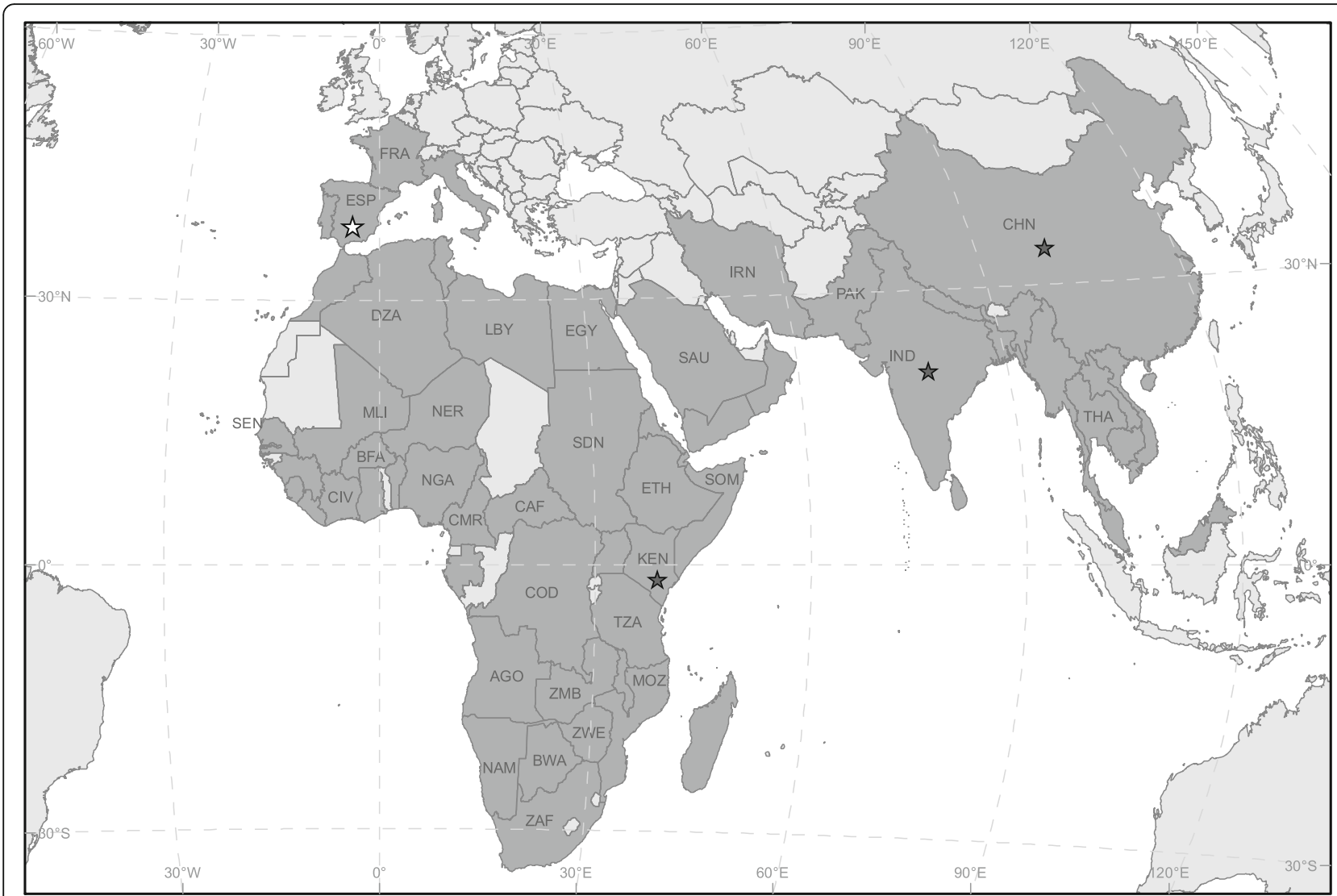

Fig. 3 Worldwide distribution of Ae. vittatus (dark grey colour). Stars indicate the geographical origin of the previously (black) and new (white) described genetic sequences of the barcoding region

Table 1 Main viruses causing diseases transmitted by Ae. vittatus with information of the potential hosts and known distribution of the diseases

\begin{tabular}{|c|c|c|c|c|}
\hline FamilyNirus & Disease & Hosts & Distribution & Reference \\
\hline \multicolumn{5}{|c|}{ Family Togaviridae (Alphavirus) } \\
\hline Babanki virus & Babanki & Humans, birds & Africa, Europe & [32] \\
\hline Chikungunya virus & Chikungunya & $\begin{array}{l}\text { Humans, birds, domestic animals, } \\
\text { monkeys, rodents }\end{array}$ & Africa, America, Asia, Europe & [33] \\
\hline Middelburg virus & Middelburg & Humans, domestic animals & Africa & [34] \\
\hline Semliki Forest virus & Encephalitis & $\begin{array}{l}\text { Humans, birds, domestic animals, } \\
\text { non-human primates, rodents }\end{array}$ & Africa, Asia, Europe & [35] \\
\hline \multicolumn{5}{|c|}{ Family Flaviviridae (Flavivirus) } \\
\hline Dengue virus & Dengue & Humans, non-human primates & Africa, South America & {$[36,37]$} \\
\hline Saboya virus & Saboya & Humans, rodents & Africa & [38] \\
\hline Wesselsbron virus & Wesselsbron & Humans, domestic animals, monkeys & Africa & [39] \\
\hline Yellow fever virus & Yellow fever & Humans, non-human primates & Africa, South America & {$[40,41]$} \\
\hline Zika virus & Zika & $\begin{array}{l}\text { Humans, bats, birds, domestic animals, } \\
\text { non-human primates }\end{array}$ & Africa, America, Asia & {$[42-44]$} \\
\hline \multicolumn{5}{|c|}{ Family Bunyaviridae (Bunyavirus) } \\
\hline Bunyamwera virus & Bunyamwera & Humans & Africa & [45] \\
\hline
\end{tabular}




\section{Conclusions}

When identifying Ae. vittatus in areas where its distribution overlaps with that of the related Asian species Ae. cogilli, the identification of the barcoding region should be combined with morphological identification and/or the characterization of other molecular markers. However, in Europe, molecular tools may allow for the accurate identification of this species due to the great genetic difference (6\%) found between Spanish Ae. vittatus and other Aedes species. Further entomological studies should be conducted in order to identify the fine-scale distribution of Ae. vittatus in European countries, where it could play a role in the transmission of viruses with public health relevance.

\section{Acknowledgments}

We thank Esmeralda Pérez, Juana Moreno Fernández and Ernesto García for their help in the fieldwork and Isabel Martín and Laura Gómez for help during laboratory work. David Aragonés and Isabel Afán (LAST-EBD) provided advice necessary to generate the maps. Members of the bank of tissues and DNA of the MNCN-CSIC helped in the deposition of samples. Two anonymous reviewers provided valuable comments in a previous version of the manuscript. Michael Lockwood revised the English text.

\section{Funding}

This study was funded by the CGL2015-65055-P project from the Spanish Ministerio de Economía y Competitividad and European Regional Development's funds (FEDER). ADF and RGL were supported by Severo-Ochoa grant (SVP-2014-068571) and a FPI grant (BES-2013-065274), respectively. JMP was partially supported by a 2017 Leonardo Grant for Researchers and Cultural Creators, BBVA Foundation. The Foundation accepts no responsibility for the opinions, statements and contents included in the project and/or the results thereof, which are entirely the responsibility of the authors. We acknowledge support of the publication fee by the CSIC Open Access Publication Support Initiative through its Unit of Information Resources for Research (URICI).

\section{Availability of data and materials}

Sequences generated in this study were deposited in the GenBank database under the accession number MF429950 Mosquitoes were deposited in the collection of the Museo Nacional de Ciencias Naturales (MNCN-CSIC), Madrid, Spain, under the accession numbers MNCN/ADN 86743 and 86744.

\section{Authors' contributions}

All authors designed the study. ADF, RGL and SR collected and morphologically identified the mosquitoes. ADF, RGL and JMP conducted the molecular analyses. ADF and JMP drafted the first version of the manuscript. All authors read and approved the final manuscript.

\section{Ethics approval}

All experimental procedures were approved by the CSIC Ethics Committee and Animal Health authorities, and complied with Spanish laws.

\section{Competing interests}

The authors declare that they have no competing interests.

\section{Publisher's Note}

Springer Nature remains neutral with regard to jurisdictional claims in published maps and institutional affiliations.

\section{Author details}

'Estación Biológica de Doñana (EBD-CSIC), Calle Américo Vespucio 26, E-41092 Seville, Spain. ${ }^{2}$ CIBER de Epidemiología y Salud Pública (CIBERESP), Seville, Spain. ${ }^{3}$ Servicio de Control de Mosquitos, Diputación de Huelva, Huelva, Spain.
Received: 28 November 2017 Accepted: 29 April 2018

Published online: 18 May 2018

\section{References}

1. Daszak P, Cunningham AA, Hyatt AD. Emerging infectious diseases of wildlife-threats to biodiversity and human health. Science. 2000;287:443-9.

2. Tomasello D, Schlagenhauf P. Chikungunya and dengue autochthonous cases in Europe, 2007-2012. Travel Med Infect Dis. 2013;11:274-84.

3. Cancrini G, Scaramozzino P, Gabrielli S, Di paolo M, Toma L, Romi R. Aedes albopictus and Culex pipiens implicated as natural vectors of Dirofilaria repens in Central Italy. J Med Entomol. 2007:44:1064-6.

4. Succo T, Leparc-Goffart I, Ferré J, Roiz D, Broche B, Maquart M, et al. Autochthonous dengue outbreak in Nîmes, South of France, July to September 2015. Euro Surveill. 2016;21:30240.

5. Rezza G, Nicoletti L, Angelini R, Romi R, Finarelli AC, Panning M, et al. Infection with Chikungunya virus in Italy: an outbreak in a temperate region. Lancet. 2007:370:1840-6.

6. Juliano SA, Lounibos LP. Ecology of invasive mosquitoes: effects on resident species and on human health. Ecol Letters. 2005;8:558-74.

7. European Centre for Disease Prevention and Control. ECDC. Guidelines for the surveillance of invasive mosquitoes in Europe. Stockholm: ECDC; 2012. https://ecdc.europa.eu/sites/portal/files/media/en/publications/Publications/ TER-Mosquito-surveillance-guidelines.pdf

8. European Centre for Disease Prevention and Control. ECDC. Guidelines for the surveillance of native mosquitoes in Europe. Stockholm: ECDC; 2014. http:/www.higieneambiental.com/sites/default/files/images/pdf/ surveillance-of_native-mosquitoes_-guidelines.pdf

9. Hebert PDN, Cywinska A, Ball SL, de Waard JR. Biological identifications through DNA barcodes. Proc R Soc Lond B. 2003;270:313-21.

10. Ondrejicka DA, Locke SA, Morey K, Borisenko AV, Hanner RH. Status and prospects of DNA barcoding in medically important parasites and vectors. Trends Parasitol. 2014;30:582-91.

11. Godfray HCJ. Challenges for taxonomy. The discipline will have to reinvent itself if it is to survive and flourish. Nature. 2002;417:17-9.

12. Dawnay N, Ogden R, McEwing R, Carvalho GR, Thorpe RS. Validation of the barcoding gene $\mathrm{COI}$ for use in forensic genetic species identification. Forensic Sci Int. 2007:173:1-6.

13. Schaffner F, Kaufmann C, Hegglin D, Mathis A. The invasive mosquito Aedes japonicas in Central Europe. Med Vet Entomol. 2009;23:448-51.

14. Paupy C, Delatte H, Bagny L, Corbel V, Fontenille D. Aedes albopictus, an arbovirus vector: From the darkness to the light. Microbes Infect. 2009;11:1177-85.

15. Wang G, Li C, Guo X, Xing D, Dong Y, Wang Z, et al. Identifying the main mosquito species in China based on DNA barcoding. PLoS One. 2012;7: e47051.

16. Murugan K, Vadivalagan C, Karthika P, Panneerselvam C, Paulpandi M, Subramaniam J, et al. DNA barcoding and molecular evolution of mosquito vectors of medical and veterinary importance. Parasitol Res. 2015:115:107-21.

17. Ajama YU, Mararo E, Omondi D, Onchuru T, Muigai AWT, Masiga D, Villinger J. Rapid and high throughput molecular identification of diverse mosquito species by high resolution melting analysis. F1000Res. 2016;5:1949.

18. Schaffner E, Angel G, Geoffroy B, Hervy JP, Rhaiem A, Brunhes J. The mosquitoes of Europe: an identification and training programme. Montpellier: IRD Editions; 2001.

19. Becker N, Petric D, Zgomba M, Boase C, Madon M, Dahl C, Kaiser A. Mosquitoes and their control. 2rd ed. Heidelberg: Springer; 2010.

20. Folmer O, Black M, Hoeh W, Lutz R, Vrijenhoek R. DNA primers for amplification of mitochondrial cytochrome c oxidase subunit I from diverse metazoan invertebrates. Mol Mar BiolBiotechnol. 1994:3:294-9.

21. Whiteman NK, Sánchez P, Merkel J, Klompen H, Parker PG. Cryptic host specificity of an avian skin mite (Epidermoptidae) vectored by louseflies (Hippoboscidae) associated with two endemic Galapagos bird species. J Parasitol. 2006;92:1218-28.

22. Gutiérrez-López R, Martínez-de la Puente J, Gangoso L, Soriguer RC, Figuerola J. Comparison of manual and semi-automatic DNA extraction protocols for the barcoding characterization of hematophagous louse flies (Diptera: Hippoboscidae). J Vector Ecol. 2015;40:11-5.

23. Young Kl, Mundis S, Widen SG, Wood TG, Tesh RB, Cardosa J, et al. Abundance and distribution of sylvatic dengue virus vectors in three different land cover types in Sarawak, Malaysian Borneo. Parasit Vectors. 2017;10:406. 
24. Ashfaq M, Hebert PDN, Mirza JH, Khan AM, Zafar Y, Mirza MS. Analyzing mosquito (Diptera: Culicidae) diversity in Pakistan by DNA barcoding. PLoS One. 2014;9:e97268.

25. Huang Y-M. Medical Entomology Studies-VII. The subgenus Stegomyia of Aedes in Southeast Asia. II - The Edwardsi group of species. III - The W-Albus group of species. (Diptera: Culicidae). Contrib Am Entomol Inst. 1977;14:1-111.

26. Bueno-Marí R, Bernués-Bañeres A, Jiménez-Peydró R. Updated checklist and distribution maps of mosquitoes (Diptera: Culicidae) of Spain. Eur Mosq Bull. 2012:30:91-126

27. Service MW. Studies on the biology and taxonomy of Aedes (Stegomyia) vittatus (Bigot) (Diptera: Culicidae) in Northern Nigeria. Ecol Entomol. 1970; 122:101-43.

28. Bueno-Marí R, Jiménez-Peydró R. Revision and new data on Aedes vittatus (Bigot, 1861) for Spain (Diptera: Culicidae). Dugesiana. 2010;17:143-4.

29. Bernués-Bañeres A, Jiménez-Peydro R. Diversity of mosquitoes (Dipter Culicidae) in protected natural parks from Valencian Autonomous Region (Eastern Spain). Biodivers J. 2013;4:335-42.

30. Service MW. The identification of blood-meals from culicine mosquitoes from northern Nigeria. Bull Entomol Res. 1965;55:637-43.

31. Wilson JJ, Sevarkodiyone SP. Host preference of blood feeding mosquitoes in rural areas of southern Tamil Nadu, India. Acad J Entomol. 2015;8:80-3.

32. Ochieng C, Lutomiah J, Makio A, Koka H, Chepkorir E, Yalwala S, et al. Mosquito-borne arbovirus surveillance at selected sites in diverse ecological zones of Kenya; 2007-2012. Virol J. 2013:10:140.

33. Vazeille M, Jeannin C, Martin E, Schaffner F. A risk for Mediterranean countries? Acta Trop. 2008:105:200-2

34. Attoui H, Sailleau C, Jaafar FM, Belhouchet M, Biagini P, Cantaloube JF, et al. Complete nucleotide sequence of Middelburg virus, isolated from the spleen of a horse with severe clinical disease in Zimbabwe. J Gen Virol. 2007;88:3078-88.

35. Fazakerley JK. Pathogenesis of Semliki Forest virus. J Neurovirol. 2002;8: 66-74.

36. Angel B, Joshi V. Distribution and seasonality of vertically transmitted dengue viruses in Aedes mosquitoes in arid and semi-arid areas of Rajasthan, India. J Vector Borne Dis. 2008;45:56-9.

37. Diallo M, Sall AA, Moncayo AC, Ba Y, Fernandez Z, Ortiz D, et al. Potential role of sylvatic and domestic African mosquito species in dengue emergence. Am J Trop Med Hyg. 2005;73:445-9.

38. Grard G, Moureau G, Charrel RN, Holmes EC, Gould EA, Lamballerie X. Genomics and evolution of Aedes-borne flaviviruses. J Gen Virol. 2010;91:87-94.

39. Diagne MM, Faye M, Faye $O$, Sow A, Balique F, Sembène $M$, et al. Emergence of Wesselsbron virus among black rat and humans in eastern Senegal in 2013. One Health. 2017;3:23-8.

40. Barrett ADT, Higgs S. Yellow Fever: A disease that has yet to be conquered. Annu Rev Entomol. 2007;52:209-29.

41. Ngoagouni C, Kamgang B, Manirakiza A, Nangouma A, Paupy C, Nakoune E, Kazanji M. Entomological profile of yellow fever epidemics in the Central African Republic, 2006-2010. Parasit Vectors. 2012:5:175.

42. Wahid B, Ali A, Rafique S, Idrees M. Zika: As an emergent epidemic. Asian Pac J Trop Med. 2016:9:723-9.

43. Vorou R. Zika virus, vectors, reservoirs, amplifying hosts, and their potential to spread worldwide: what we know and what we should investigate urgently. Int J Infect Dis. 2016;48:85-90.

44. Diallo D, Sall AA, Diagne CT, Faye O, Faye O, Ba Y, et al. Zika virus emergence in mosquitoes in southeastern Senegal, 2011. PLoS One. 2014;9:e109442.

45. Odhiambo C, Venter M, Limbaso K, Swanepoel R, Sang R. Genome sequence analysis of in vitro and in vivo phenotypes of Bunyamwera and Ngarivirus isolates from Northern Kenya. PLoS One. 2014;9:e105446.

\section{Ready to submit your research? Choose BMC and benefit from:}

- fast, convenient online submission

- thorough peer review by experienced researchers in your field

- rapid publication on acceptance

- support for research data, including large and complex data types

- gold Open Access which fosters wider collaboration and increased citations

- maximum visibility for your research: over $100 \mathrm{M}$ website views per year

At BMC, research is always in progress.

Learn more biomedcentral.com/submissions 